\title{
Development of a Cross-Project Citizen Science Platform for the Humanities
}

Hendrikje Carius [1], Christiane Kuller [2], Patrick Rössler [3] \& René Smolarski [4]

[1] Gotha Research Library of the University of Erfurt

hendrikje.carius@uni-erfurt.de

https://orcid.org/0000-0002-8413-2355

[2] Chair of Modern and Contemporary History and History Didactics, University of Erfurt christiane.kuller@uni-erfurt.de

[3]ChairofCommunicationSciencewith thefocuson EmpiricalCommunication Research / Methods, University of Erfurt

patrick.roessler@uni-erfurt.de

[4] Modern and Contemporary History and History Didactics, University of Erfurt

rene.smolarski@uni-erfurt.de

https://orcid.org/0000-0001-8854-4341

Keywords: Citizen Science, Virtual Research Infrastructure, Public History, Cinema History, History of Everyday Life in the GDR

\begin{abstract}
This article presents a project at the University of Erfurt to establish a Citizen Science platform on the issue of GDR Cinema History. Public interest assumed for this topic will be activated by both analogous and digital communication, contributions collected online and integrated into the research process.
\end{abstract}

Genuine digital approaches have become firmly established components of Citizen Science or Crowdsourcing projects. In the course of the public and digital turn in research and the knowledge society, they contribute to a linkage between science and the public. This opens up fresh opportunities for an approach, which, in the sense of a broad definition of Citizen Science, includes the dialogue with an interested public as an integral part of a research process that expands beyond the unidirectional information and education function and rather relies on dialogue-oriented and participatory formats. ${ }^{1}$

Citizen Science has been established in Germany through initiatives such as the GEWISS consortium Bürger schaffen Wissen (Citizens Create Knowledge), ${ }^{2}$ primarily in the natural sciences, and has been

1 For Citizen Science in the humanities see among others: Kristin OswaLD / René SMOLARSKI, Ed., Bürger Künste Wissenschaft. Citizen Science in Kultur und Geisteswissenschaften, Gutenberg 2016; Cord ARENDES, Historiker als „Mittler zwischen den Welten"? Produktion, Vermittlung und Rezeption historischen Wissens im Zeichen von Citizen Science und Open Science, in: Heidelberg Jahrbücher Online 2 (2017), 19-58.

2 The consortium is funded by the German Federal Ministry of Education and Research (BMBF) and coordinated by the Museum für Naturkunde Berlin - Leibniz Institute for Evolutionary and Biodiversity Science (MfN) and the Helmholtz Centre for Environmental Research (UFZ). 
tested in numerous projects. ${ }^{3}$ Since then, a number of successful projects have also been implemented in the humanities and social sciences. These include, for example, those that aim to involve Citizen Scientists in the creation of transcriptions, such as Transcribe Bentham, Transcribe Europeana 19141918, e-manuscripta and Letters $1916-1923^{4}$, or projects to identify or collect objects such as Artigo. ${ }^{5}$

The existing digital infrastructures for Citizen Science projects in the humanities are usually oriented towards individual projects and data acquisition and do not offer a structure that works across different projects which thus remains a desideratum so far. This is the starting point for an interdisciplinary and infrastructural project to set up a Citizen Science platform at the University of Erfurt. ${ }^{6}$ Based on an issue, which is relevant for everyday history in the GDR, we will lay an infrastructural basis for systematic cooperation between citizens and academic institutions, test new concepts for the integration of Citizen Science into academia, reflected from the perspectives of information, history and communication studies. The concept of Citizen Science is understood in a broad sense as the participation of the (non-specialist) public in various phases of research processes in compliance with academic standards. ${ }^{7}$

The project is designed as an interdisciplinary cooperation and based on two research units: the Network for Digital Humanities and Citizen Science and the Interdisciplinary Research Centre for Historical Media at the University of Erfurt, supported by the Chairs of Modern and Contemporary History and History Didactics as well as the Chair of Communication Studies with a focus on Empirical Communication Research / Methods. In the field of IT, the project cooperates with the Technical University of IImenau, with the Gotha Research Library of the University of Erfurt representing another partner during the stage of conception. The project will use and evaluate established solutions to develop generic, sustainable infrastructures in order to build a technical foundation for different Citizen Science initiatives within the modular digital research environment at the University of Erfurt. ${ }^{8}$

Based on a concrete case study entitled "Kino in der DDR - Rezeptionsgeschichte ,von unten"' (Cinema in the GDR - a bottom-up History of Media Use), we address the public's interest in the humanities and social sciences. People are activated for university research using digital methods; they are connected and productively integrated into the academic work process. ${ }^{9}$ Non-university citizens can participate in various panels and in different stages of the research process (data collection, processing and evaluation). Their activities include a broad spectrum of image and text classifications, transcription and annotation work, and other forms of evaluation of historical collections and data.

3 An overview of international Citizen Science projects can be found on Wikipedia: List of citizen science projects, online unter: https://en.wikipedia.org/wiki/List_of_citizen_science_projects (30.03.2019).

4 Transcribe Bentham, online unter: https:///blogs.ucl.ac.uk/transcribe-bentham/; Transcribathon, online unter: https://transcribathon.com/en/; e-manuscripta, online unter: https://www.e-manuscripta.ch/; Letters 1916-1923, online unter: http:// letters1916.maynoothuniversity.ie/ (all 30.03.2019).

5 Artigo, online unter. https://www.artigo.org/ (30.03.2019).

6 The project "Development of a Citizen Science Platform to Involve the Public in the Scientific Work Process at the University Erfurt" will be funded by the Thüringer Aufbaubank in 2019-2022.

7 Lisa Pettibone et al., Ed., Citizen Science für alle. Eine Handreichung für Citizen Science Beteiligte, Berlin 2016, 6.

8 One example is the Gotha Portal, which is being created as part of the Sammlungs- und Forschungsverbund Gotha (Research Library and Research Centre of the University of Erfurt, Foundation Castle Friedenstein Gotha) and unites the resources of the research location on digital grounds. Interfaces are to be implemented between the planned research environment and the Citizen Science Portal for worldwide research with historical objects and collections. See: Forschen in Gotha, online unter: https://www.gotha3.de/forschungsblog/forschen-in-gotha/gotha3/gotha-portal (30.03.2019).

9 See knowledge transfer formats such as Science Slams, Long Nights of the Sciences/Museums or Science Café as well as the participation of citizens in relevant topics such as numismatics, philately or genealogy. Cooperation is also planned with "Bürger schaffen Wissen" and other international communities. 


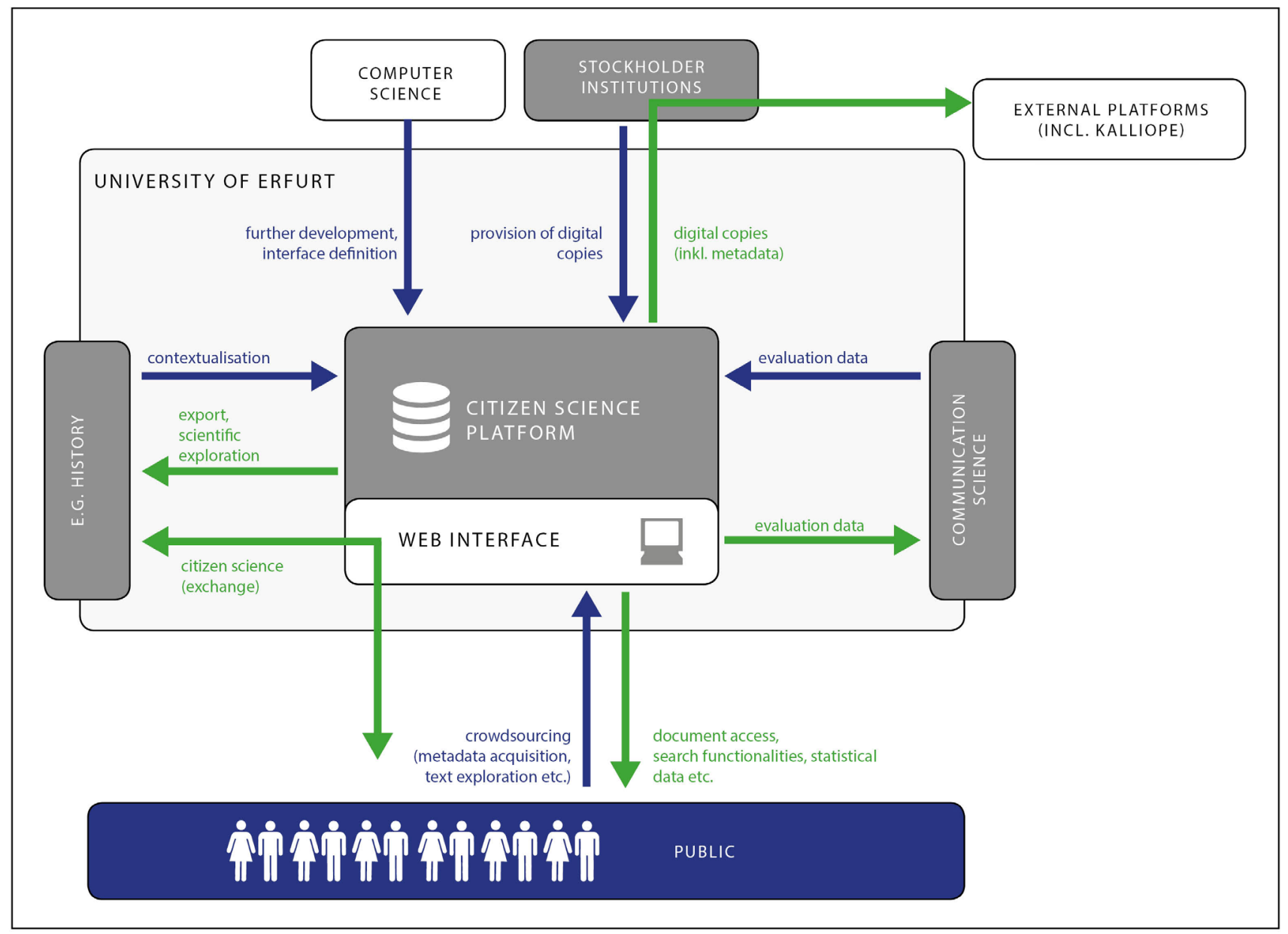

Fig. 1: Overall structure of the project

Methodologically, approaches of Digital Humanities and Citizen Science as well as from communications, computer science and history are intertwined. Our multi-perspective approach combines the analysis of the functional conditions of Citizen Science communication with the informational and technological conception and the realization of the platform. This also includes the use of elements typically used for computer games to increase motivation (gamification). In the pilot project, conceptual questions concerning the process (cooperation, interaction and negotiation of roles between the individual actors; community building and management; user expectations and recognition culture), data curation, quality assurance as well as the conditions of the legal and ethical framework will be reflected.

Especially in the field of GDR history, instruments which facilitate the exchange between university research and non-academic debates still are a desideratum. Thus far, the film history of the GDR has been written primarily as a history of film politics, ${ }^{10}$ content analysis ${ }^{11}$ or production history, ${ }^{12}$ while a historical account detailing the reception of these films is still lacking in many respects. Using Citizen Science and Crowdsourcing approaches, the project thus attempts for the first time to reconstruct the appropriation of movies based on narratives and documents from the private sphere, in order to close the existing source gap.

10 Dagmar SchItTly, Zwischen Regie und Regime. Die Filmpolitik der SED im Spiegel der DEFA-Produktionen, Berlin 2002.

11 Klaus FINKE, Politik und Film in der DDR, Oldenburg 2007.

12 Günter JoRDAN, Film in der DDR. Daten, Fakten, Strukturen, Potsdam 2009. 
The unique holdings of the Interdisciplinary Research Centre for Historical Media at the University of Erfurt (IRCHM) on cinema films in the GDR form one of the sources for the pilot project. The IRCHM has around 150,000 individual objects at its disposal, including film posters, stills, press photos and other advertising material. The collection covers almost all films screened in the GDR since the mid1950 s, i.e. the holdings consist not only of the GDR's own DEFA productions, but as well of all productions from eastern and western countries permitted for screening via the central Progress Film-Verleih (film distribution), plus materials on those films banned by the GDR government's censorship.

On the one hand, the platform is intended as an opportunity of, in the sense of a crowdsourcing approach, sharing self-experienced stories and additional source material via upload. This provides new information and sources related to the everyday history in the GDR that could not be obtained otherwise since most of this evidence can only be retrieved from contemporary witnesses. However, traditional methods of data collection would be far too extensive in this realm. Moreover, the narratives prevalent in society add specific evidence when the legitimacy and recognition of different narratives is being fought over currently in a particularly conflictual manner. Reflecting on the dialogue between academia and public, the Citizen Science platform will generate benefit for the digital-based Citizen Science and its methodology in general, as well as for the associated fields such as gamification, e-learning and media studies.

\section{Literature}

Cord ARENDES, Historiker als „Mittler zwischen den Welten“? Produktion, Vermittlung und Rezeption historischen Wissens im Zeichen von Citizen Science und Open Science, in: Heidelberg Jahrbücher Online 2 (2017), 19-58.

Artigo, online unter: https://www.artigo.org/ (30.03.2019).

e-manuscripta, online unter: https://www.e-manuscripta.ch/ (30.03.2019).

Klaus FINKE, Politik und Film in der DDR, Oldenburg 2007.

Forschen in Gotha, online unter: https://www.gotha3.de/forschungsblog/forschen-in-gotha/gotha3/gotha-portal (30.03.2019).

Günter JoRDAN, Film in der DDR. Daten, Fakten, Strukturen, Potsdam 2009.

Letters 1916-1923, online unter: http://letters1916.maynoothuniversity.ie/ (30.03.2019).

List of citizen science projects, online unter: https://en.wikipedia.org/wiki/List_of_citizen_science_projects (30.03.2019).

Kristin Oswald / René Smolarski, Ed., Bürger Künste Wissenschaft. Citizen Science in Kultur und Geisteswissenschaften, Gutenberg 2016.

Lisa Pettibone et al., Ed., Citizen Science für alle. Eine Handreichung für Citizen Science Beteiligte, Berlin 2016.

Dagmar SchITTLY, Zwischen Regie und Regime. Die Filmpolitik der SED im Spiegel der DEFA-Produktionen, Berlin 2002.

Transcribathon, online unter: https://transcribathon.com/en/ (30.03.2019).

Transcribe Bentham, online unter: https://blogs.ucl.ac.uk/transcribe-bentham/ (30.03.2019). 